\title{
Magnetic Places in Riga Soviet Residential Areas
}

\author{
Agnese Sofija Kusmane, Latvia University of Life Sciences and Technologies
}

\begin{abstract}
This article focuses on magnetic places in Riga Soviet residential areas - locations which are differ from ordinary spaces due to their naturalness, possibility of restoration, perceived beauty and possibility to appropriate such places. This paper utilises two theoretical fields - the one of evolutionary aesthetics in dealing with such elements as prospects and refuges that is crucial for survival, but also phenomenology dealing with mental maps and subjective perception of space. The method in use is semi-structured interviews, since they provide a valuable in situ material for proving a theoretical thought. It can be concluded that the magnetic places that often are as much as $200 \mathrm{~m}$ far from the interviewees' homes are more attractive than the location outside their window. This finding is in stark contrast to Oscar Newman's Defensible Space Theory. There are also few recommendations for landscape architects included in this text: one of those is to not only invest more resources into the design of magnetic places, but carefully design the ordinary places. The latter should be done not only in order to avoid the arousal of no-go areas in a residential complex, but also because any ordinary space has a potential of becoming a place.
\end{abstract}

Keywords: space, place, magnetic place, evolutionary aesthetics, phenomenology

\section{Introduction}

Previous research of the author of this paper was focused on the question whether or not there is a metric system that underlies the preference of public spaces in urban settings. In many yards and streets of the Soviet housing areas in Riga, Latvia, which was the research field, it was possible to detect by the help of open-ended interviews the objects that formed the perceived borders of these spaces. Such objects were not only walls of the buildings but most importantly also trees, elevations, water features, benches. It became clear that the perceived size of the space together with reported presence of elements such as prospects and refuges corelates with liking or disliking this space $[10 ; 11]$. Prospect is a possibility to see into the landscape and gather more information than available at the moment, but refuge - an opportunity to hide. Both are crucial for survival [1; 7]. Yet, in few cases the interviewees did not have much to report and showed no interest on yards or streets they were asked about: neither in the context of size perception and liking, nor with regard to prospects and refuges. This phenomenon of being reserved even about the locations very close to the doors to their homes always happened when there was a strikingly beautiful area in the proximity of the housing ensemble. This area seemed to be able to make perception and also preference ranking of other spaces difficult. The strikingly beautiful locations tended to blend out other, "ordinary" spaces in the area from our conversations. Such locations are called magnetic places by the author of this paper. The existence of these seldom locations asserts that one of theories used in contemporary landscape architecture - Oscar Newman's Defensible Space Theory - which proposes that the locations near to one's home are the most dear to the inhabitants and thus defensible, might have some deficits [14]. The goal of this article is to characterise magnetic places and point to the possible implementation of this concept into landscape architecture.

One of the theoretical thoughts that can explain the liking of magnetic places themselves is evolutionary aesthetics. The magnetic spaces are natural locations and thus their liking can be easly associated with biophilia concept popular in the evolutionary aesthetics [19]. Also, prospect and refuge theory can shed a light on such a high preference. A good number of such elements corelates with human calculus of better survival options according to Prospect and Refuge Theory [1]. Besides that, such an environment is capable to restore the resources of direct attention needed in the everyday as Attention Restoration Theory promotes it [8]. Yet, opposed to ordinary yards and streets, the magnetic places are not measurable in meters. Their perceived borders are not visible as their impact exceeds beyond the site. On contrary, many magnetic places attract people from afar. This attraction makes the places magnetic. Hence, the field of their influence is called magnetic field.

Even though, the content of magnetic places can be explained in the language of evolutionary aesthetics, the perception of their borders needs a very different theoretical framework. Magnetic places are the locations that can be seen partly only. Their size is bound to subjective experience, their borders often lay beyond the site, their meaning is subjective, emotional. Magnetic places resamble the concept of a place elaborated by phenomenologists, who differentiate 
between space and place. Space is more abstract than place. „What begins as undifferentiated space becomes place as we get to know it better and endow it with value" states Tuan [18]. "Place is a meaningful location", writes human geographer Tim Cresswell [3]. Also philosopher Edward S. Casey describes places similarly: "place as experienced by human beings, in contrast to space, whose abstractness discourages experiential explorations" [2]. Concept of place differs from the one of space by the level of experiencing it. "A person is more attached to place and he or she is to a very small degree attached to space" [2]. Casey argues that spaces that can be embodied have the potential of becoming places [2]. Casey also states that "\%./ the body not only goes out to reach places; it also bears the traces of the places it has known." He terms these processes "Outgoing" and "Incoming" [2]. The interview material on some locations resembles the above mentioned quotes in a nutshell: these places are meaningful, worth experiencing, they possess a great deal of the degree of attachment, their traces are well embedded into residents' bodies and memory. Thus, the hypothesis of this paper is as follows: if there is a magnetic place in a Soviet Residential area it intensively attracts inhabitants who want to spend some leisure, but more importantly such space diminishes the apprehension and attachment to ordinary spaces.

\section{Methods and Materials}

The primary tool for inquiring data on magnetic spaces was open-ended interviews with the inhabitants of four Soviet time residential areas in Riga, Latvia: Ägenskalna priedes, Kengarags, Zolitūde, Leñina (now Brīvības) iela 177. The route of the interviews was always prechosen. Also, the spaces that the conversations were about were established by the researcher in advance. They included both, locations next to the entrance of respondent's home such as a yard or street that can be seen out of the window as well as spaces that were as much as $500 \mathrm{~m}$ away from that entrance. The interviews were originally designed to assemble material on liking as well as size perception of spaces. Open ended interviews were selected as they provide the best possibility to comprehend spatial issues that have a good theoreticaly grounded understanding, but not empirical in situ based one $[10 ; 6]$. Yet, as a positive side-effect of a semistructured conversation - such interviews bring along also unpredicted topics. So called magnetic places are one of them. Discourse analysis is applied to the interview material to detect the inhabitant's utterances on these particularly attractive locations in their areas.

For the purpose of this paper the main discourse the author is filtering out of the interviews - avoidance to talk about the particular yard or street when asked and leaning towards speaking about the magnetic place instead. Such a change of the interview course signals that the interviewee is attracted by the magnetic field as mentally and subjectively they are in a magnetic place even though physically they are in a very different location - yard next to their home, for instance.

The next method applied once the magnetic place is established: evaluating it from the point of view of presence of prospects and refuges in it. Such a look to any location gives the researcher the understanding on why the place is being liked.

Furthermore, because as opposed to ordinary spaces the magnetic places have no objectively measurable borders, another approach is needed to understand their subjective amplitude. The magnetic places will be rendered from the point of view phenomenological place. This will show the subjective range of these locations. This step is essential in dealing with the material: it helps to understand why some spaces become places? Is it because they promise restoration? Or perhaps they are easier to appropriate?

\section{Results and Discussion}

By analysing the interview material, it was discovered that three out of four residential areas had at least one magnetic space in close proximity. In Kengarags such a space is Daugava river promenade, in Zolitūde - an alley of trees on the outskirts of the residential area, in Lenina ielaformer cementery Lielie kapi that serves as a park now. The only housing ensemble where no magnetic place was discovered was Ägenskalna priedes. It means that here residents did not have any particular place that they felt was so supreme that made thinking and talking about other locations redundant.

Not all three magnetic places have the same power of attraction, magnetic field in other words. Daugavas promenade in Kengarags seemed to have a very persistent and intensive influence on how the inhabitants perceived and liked other locations in this housing ensemble. Also, Lielie kapi in Lenina iela residential complex was mentioned quite often by the inhabitants as the actual place of spending time that out shadowed the yard of the estate. The utterances about the tree alley in the outskirts of Zolitūde can also be interpreted as descriptions of a magnetic place, but they are not as intensive as the previous two.

All three magnetic places can be visually characterised in multiple ways. For instance, they are natural locations, at least if the amount of water, animals, birds, trees or other plants in such spaces is compared to their presence in the yards and on the streets of the residential area in question. Accordingly, the built portion of magnetic places is 
very small. There is perhaps a pedestrian road, a monument, an embankment in such a space. Another important aspect that can be applied generally to all three magnetic places, there are no large obstacles - walls or intensive streets - between the inhabitants home and a magnetic place. Besides that, the interviews register a distance that is no longer than $200 \mathrm{~m}$ between the home and the magnetic place. A look at two magnetic places bellow gives some more precise detail on this phenomenon.

\section{Daugava river bank}

One of them is a $25 \mathrm{~m}$ wide promenade that is situated along the elevated part of Daugava river bank. On one side it is bordered by the facades of residential area Kengarags houses and green intervals between them. Both, facades and green intervals are ca. $50 \mathrm{~m}$ long. The other side of the promenade is dotted by trees. Further, there is a slope between water and pathway. The river here is ca. $500 \mathrm{~m}$ wide. Yet, the sight can wander significantly further along it. Daugava is meandring slightly at this section (Figure 2).

From the view point of evolutionary aesthetics this landscape manifests quite a few prospects and refuges. The meandering river and also the steep slope is forming prospects: moving along the curbed path or down the slope provides a new perspective and thus information about the location. The water in its turn host many elements of refuge - one can hide in the water and observe the scene in such a way that gives an overview not possible from the promenade. The trees with low growing branches in this case are refuges, too. One can climb onto them and escape a danger. The abundance of all the mentioned elements is the one of the reasons why this scene is loved by the inhabitants. There are certainly more of prospects and refuges than in the neighbouring yards and streets (Figure 1).

The inhabitants demonstrated love and affection towards Daugava river promenade. A young adult Martins said that there was no other place like Daugava river promenade in the city. A retired woman Jevgenia proudly described the promenade as very "posh". Almost everyone interviewed in this area used positive superlatives to describe their relationship to Daugava river promenade. This affection or liking in other words can be explained by the above mentioned numbers of prospects and refuges [4].

Inhabitants also explained that this is the place where they relax, both their eyes and mind. They found it very peaceful here. A place to forget the everyday, they said. According to the Attention Restoration Theory, such a place renews the resources of the direct attention that are needed to function and make decisions.

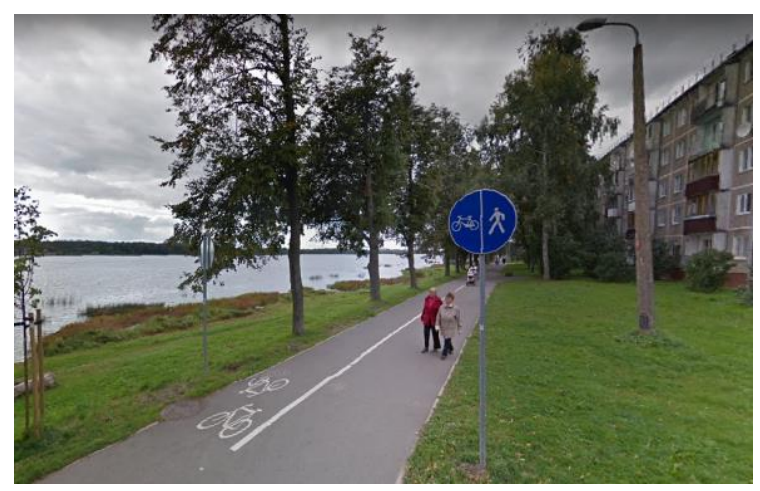

Fig. 1. A view to Daugava river promenade in Kengarags, Riga. Photo courtesy of Google Maps.

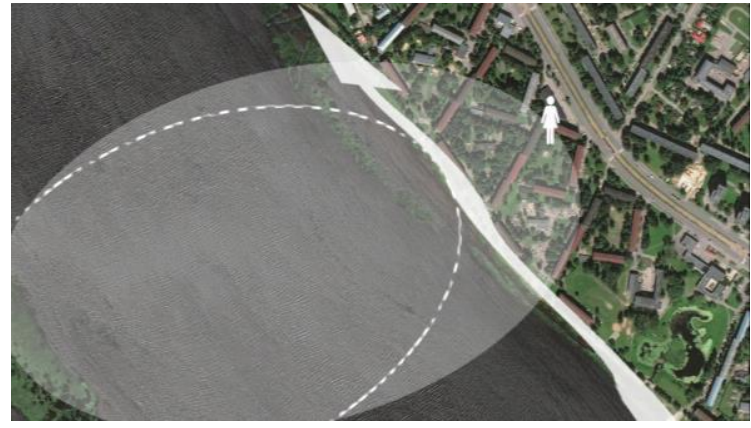

Fig. 2. A smaller transparent circular area represents the visual field seen from the banks of river when walking along the promenade (white arrow). Larger transparent circular field shows the amplitude of Daugava river on a mental map of a resident (white symbol of a female), which extends until their

home. Photo courtesy of Google Maps and author.

However, evolutionary aesthetics cannot explain the perception of the size of Daugava river promenade. Of course, the space that can be seen from the promenade can be demarcated on the paper map (Figure 2). Yet, the borders of the very same space on the residents" mental maps to use Tuan's concept are much larger. Subjectively the Daugava river promenade extends as far as until the large Maskavas iela, which physically cannot be even seen from the promenade. Moreover, its meaning surpasses the meaning of a next-tohome-yard in such a way that the interviewees even avoid a conversation about the yard.

To demonstrate this point I will describe two interviewees that are symptomatic to the rest. For instance, 30 years old mother of a toddler Olga, was asked about the largest yard in the residential area that is seen outside her window. She refused to call it a yard and reffered to it as a place to jog. She also emphasized thad she felt her yard was everywhere in the area, where one could descend the bank of Daugava, sit down and think. Olga stressed that Kengarags was a very beautiful residential area. Also, Alla whose residential block is situated on Maskavas street $200 \mathrm{~m}$ away from Daugava, when asked if she used her yard, replied without hesitating a moment with a no. She always went to Daugava river instead. These answers indicate that Daugava river banks are mentally the closest location used for 
regeneration. Daugava river banks replace their yard. Figures show the extent of magnetic place for both quoted interviews.

From the point of view of phenomenology the Daugava river bank is endowed with a value to use Tuans expression [19]. According to the interviews it is beautiful, posh, enables thinking, is usable for walks, bike rides and jogging. Aesthetic and functional value of this environment is very distinct almost in every interview. These elements turn a space into place. The inhabitants not only enjoy but also appropriate the bank. Potentially this extraordinary significance of the promenade is the reason why the size of it much larger on the mental map than it is on the physical one. Even standing $200 \mathrm{~m}$ away from the bank inhabitants feel attracted to Daugava. This is truly magnetic place.

\section{Lielie kapi}

Another example is Lielie kapi near the housing ensemble in Lenina (now Brīvības) iela 177. Lieli kapi is a cemetery. First burials took place at the end of the 18th century, but the last ones ca. 60 years ago. The size of the cemetery is 22 ha. A rather busy Senču iela runs through it, deviding the space in two asymmetrically large parts. The larger one of ca. 17 ha is closer to the estate in question. Significant portions of the cemetery were destroyed during the Soviet times and it was turned into a park. Yet, some of the tombstones and memorial buildings are still present. The greenery is composed of large trees with high growing branches, there is also no underwood. Both of the factors potentiate far reaching visual fields. The cemetery paths are mostly designed as straight roads (Figure 4).

From the point of view of evolutionary aesthetcis, this green area possesses a large number of refuges as every memorial building on the sight serves as one. These small built structures can serve as a hiding place in case of danger. Also, there are multiple prospects, formed by the groups of trees. Walking behind those groups promises new pieces of information - a component necessary for survival. The presence of prospect and refuge elements theoretically explains the liking of Lielie kapi by the inhabitants (Figure 3). The presence of these elements in the residential area itself is much smaller.

Empirically the case of Lenina iela demonstrates very similar contents of quotes regarding the affection and liking of Lielie kapi as it was in case of Daugava river banks in Kengaraga. Men and women interviewed seem to appreciate Lielie kapi peacfulness and fresh air. They are also delighted by their ways to the park - Indranu iela - an aproximately $80 \mathrm{~m}$ long stretch of a side street bordered by two to three stories high historic residential houses.

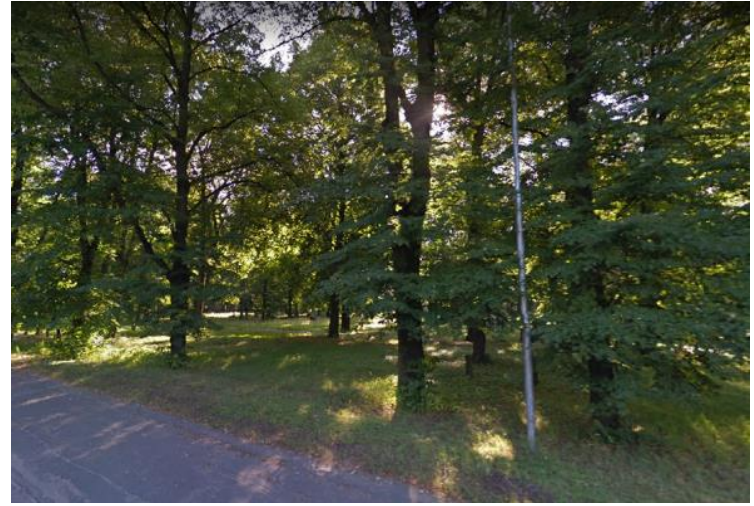

Fig. 3. A view to Lielie kapi, Riga. Photo courtesy of Google Maps.

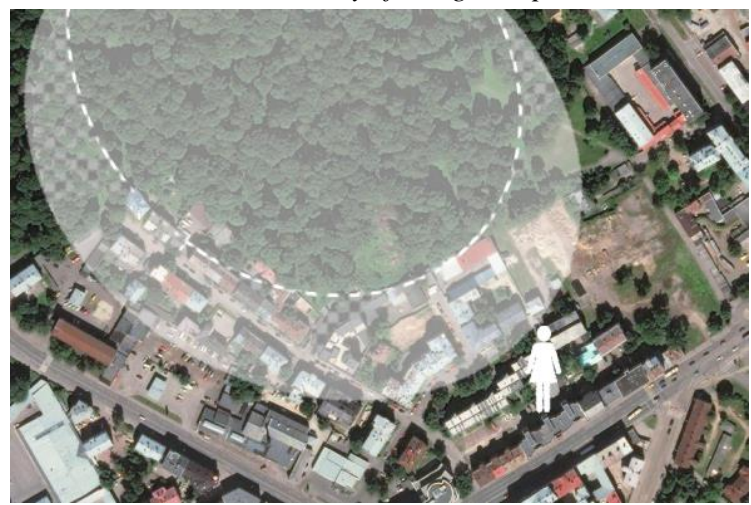

Fig. 4. A smaller transparent circular area represents the visual field seen from entrance to the park. Larger transparent circular field shows the amplitude of Lielie kapi on a resident's mental map (white symbol of a female), which extends until their home. Photo courtesy of Google Maps and author.

The interviewees also mention couple of times that they use Lielie kapi to relax from the city noises. This relaxation from the overstimulated city life that is possible in the cementary can be explaind by ART - the place has a property of restoring direct attention.

Yet, also in this case evolutionary aesthetics cannot explain the size of Lielie kapi on the mental maps of the inhabitants. When 18 years old Rihards was asked standing in the yard of Lenina iela 177 estate about his favourite place in this residential complex, he answered it was the park. Meaning of course the Lielie kapi cementary which has been turned into the park. For him this green area was part of the residential area, even though technically they are separated by housing of a very different era and a distance of ca. $150 \mathrm{~m}$. (Figure 4) Also 37 years old Rihards and 38 years old Markes gave a similar answer. Some other asked to name the place in the residential area where they would read a book, mentioned park, too.

From the phenomenological perspective quotes of the inhabitants on Lielie kapi show that this is the location that they appropriate more intensively that their yard. Some come here to walk a dog, some - to read a book, some - to relax. These are all the activities that they do no excercise in the yards or 
streets next to their homes. In other words, the inhabitants demonstrated the expressions of joy over possibility to freely function and appropriate Lielie kapi. In Casey's words the places are experienced. Lielie kapi is the location that encourages experiential explorations, in contrast to spaces which due to being so abstract, avert any wish to explore them. Also, in the case of Lenina iela 177 ensemble, the residents being interviewed in the yard or on the street feel attracted to the Lielie kapi much more than they are to the yard that they can see outside of their window. This phenomenon makes Lielie kapi magnetic place.

\section{Conslusion}

The following characteristic signs of magnetic places have been discovered in this paper: they are natural locations with multitude of prospects and refuges - fact that permits to relax the direct attention. This argument is in line with most of the environmental psychology literature on the topic $[8 ; 17 ; 5 ; 16 ; 12]$. They are also locations that have a high subjective value because of their aesthetics beauty and appeal to appropriate them. This finding resembles the one done by many phenomenologists who argue that places opposed to spaces are endowed with subjective value and encourage explorations $[2 ; 13 ; 18]$. Also, magnetic places are borderless in the sense that one cannot really see their borders.

Moreover, they are easy to reach and there are no obstacles like intensive traffic between ordinary spaces and magnetic places. Because of their high value the magnetic places attract inhabitants from locations that are as $200 \mathrm{~m}$ far away. Hence, they are called magnetic places and the range of their attraction - magnetic field. Thus, the hypothesis that a magnetic place outcompetes the perception and likability of ordinary space next to residents' homes is proved. This last conclusion is in strong disagreement with the very popular Defensible Space Theory [14; 15], which teaches us that the location closer to one's home are the most cherished ones.

Discovery of magnetic places in any residential area should signal to landscape architects dealing with it that investing larger resources into its reconstruction is meaningful, since the inhabitants are heavily attracted to them. It does not mean yet that ordinary spaces such as yards and streets should be neglected by landscapes architects and thus become a no-gozones of the residential areas. For also spaces have a potential to become places [2].

The interviews were not designed to discover magnetic places specifically. Another project with specific questions is needed to address this issue.

\section{References}

1. Appleton, J. The experience of landscape. New York: Wiley, 1975.

2. Casey, E. S. Between Geography and Philosophy: What Does It Mean to Be in the Place-World? Annals of the Association of American Geographers, 2001, Vol. 91, p. 683-693.

3. Cresswell, T. Place. A Short Introduction. Malden: Blackwell Publishing, 2004.

4. Herzog, T. R. A Cognitive Analysis of Preference for Urban Spaces. Journal of Environmental Psychology, 1992, Vol. 12, p. 237-248.

5. Herzog, T. R., Smith, G. A. Danger, Mystery, and Environmental Preference. Environment and Behavior, 1988, Vol. 20(3), p. 320-344.

6. Holton, M., Riley, M. Talking on the Move: Place-Based Interviewing with Undergraduate Students. Area, 2014, Vol. 46, p. 59-65.

7. Kaplan, S. Aesthetics, Affect, and Cognition - Environmental Preference from an Evolutionary Perspective. Environment and Behavior, 1987, Vol. 19, p. 3-32.

8. Kaplan, R., Kaplan, S. The Experience of Nature: A Psychological Perspective. Cambridge: Cambridge Univ. Press, 1989.

9. Kusenbach, M. Street Phenomenology. The Go-Along as Ethnographic Research Tool. Ethnography, 2003, Vol. 4, p. 455-485.

10. Kusmane, A.S. How to Measure the Impact of Spatial Aesthetics on the Everyday in Soviet Housing Estates? Landscape Architecture and Art: scientific journal of Latvia University of Life Sciences and Technologies. Jelgava: LLU, 2016, Vol. 9., pp. 7 - 20.

11. Kusmane A.S., İle U. Importance of Landscape elements in perception of Spatial Aesthetics in Residential Areas. Research for Rural Development: international scientific conference proceedings. Jelgava, LLU, 2017, Vol, 1, p. 187-194.

12. Lindal P. J., Hartig T. Architectural variation, building height, and the restorative quality of urban residential streetscapes. Journal of Environmental Psychology, 2012, Vol. 33, p. 26-36.

13. Massey, D., Space, Place and Gender. Cambridge: Polity Press, 2013.

14. Newman O. Creating Defensible Space. New Brunswick: Rutgers University, 1966.

15. Reynald, D. M, Elffers, H. The Future of Newman's Defensible Space Theory: Linking Defensible Space and the Routine Activities of Place. European Journal of Criminology, 2009, Vol. 6, p. 25-46.

16. Stamps, A. E., Smith, S. Environmental Enclosure in Urban Settings. Environment and Behavior, 2002, Vol. 34, p.781-794.

17. Thiel, P., Harrison E. D., Alden, R. S. The Perception of Spatial Enclosure as a Function of the Position of Architectural Surfaces. Environment and Behavior, 1986, Vol. 18, p. 227-245.

18. Tuan, Y.-F. Space and Place. The Perspective of Experience. Minnesota: University of Minnesota Press, 1977.

19. Wilson, E. O. Biophilia. Cambridge: Harvard University Press, 1984. 


\section{INFORMATION ABOUT THE AUTHOR:}

Agnese Sofija Kusmane is a doctoral student of landscape architecture at Latvia University of Life Sciences and Technologies. She is interested in relationship between spatial aesthetics and behaviour. E-mail: kusmane@googlemail.com

Kopsavilkums. Raksts pēta tā sauktās magnētiskās vietas lielmēroga dzīvojamajos rajonos Rīgā, kuras atškiras no parastajām telpām ar īpaši lielu dabisku zonu klātbūtni, ar iespēju tajās rekonstruēt mentālās kapacitātes un apropriēt tās. Magnētiskajām vietām piemīt arī īpaši augsta uztvertā estētiskā vērtība. Raksts apskata magnētiskās vietas no divu teorētisko lauku viedokḷa - evolucionārā estētika un fenomenologija. Pirmā izvērsti pēta skatu un slēpṇu klātbūtni magnētiskajās vietās, tie ir ainavāa atrodami elementi, kuri cilvēka sapratnei signalizē izdzīvošanas potenciālu. Savukārt no fenomenoloǵijas viedokḷa tekstā apskatîta magnētisko vietu subjektīvā un emocionālā vērtība.

Rakstā secināts, ka magnētiskās vietas respondentuprāt ir daudz pievilcīgākas, kā parastās telpas, t.i., tām ir liels magnētiskais lauks. Liela magnētiskā lauka fenomens ir vērojams pat gadījumos, kuros magnētiskās vietas atrodas pat $200 \mathrm{~m}$ atstatumā no respondentu dzīves vietas, bet parastās telpas - redzamas pa mājokḷa logu. Magnētisko vietu eksistenci iespējams izskaidrot gan ar lielo skatu un slēpṇu skaitu no evolucionārās estêtikas viedokḷa, gan no vietas teorijas (place theory) skatpunkta, kas populārs fenomenoloǵijā. Taču magnētisko vietu fenomens ir pretstatā tam, ko postulē Oskara N̦ūmena (Oscar Newman) Aizsargātas telpas teorija (Defensible Space Theory), kura paredz, ka visciešākā saistība iedzīvotājiem ir tieši ar telpām, kas atrodas vistuvāk mājvietai.

Raksts rekomendē ainavu arhitektiem veicināt resursu ieguldījumu magnētiskajās vietās. Tomēr ainavu arhitekti tiek aicināti, neaizmirst arī parastās telpas, jo katrai telpai piemīt potenciāls kḷūt par vietu. 